Фартушний І.Д. канд. фіз.-мат. наук, доцент ORCID ID: 0000-0003-1595-9495

Пузирна К.М. Національний технічний університет України «Київський політехнічний інститут імені горя Сікорського»

\title{
ЕКОНОМІКО-МАТЕМАТИЧНЕ МОДЕЛЮВАННЯ ВИРОБНИЧОӤ ДІЯЛЬНОСТІ ПІДПРИЄМСТВА ЛЕГКОЇ ПРОМИСЛОВОСТІ
}

\section{ЭКОНОМИКО-МАТЕМАТИЧЕСКОЕ МОДЕЛИРОВАНИЕ ПРОИЗВОДСТВЕННОЙ ДЕЯТЕЛЬНОСТИ ПРЕДПРИЯТИЯ ЛЕГКОЙ ПРОМЫШЛЕННОСТИ}

\section{ECONOMIC-MATHEMATICAL MODELING OF MANUFACTURING ACTIVITY IN THE LIGHT INDUSTRY ENTERPRISE}

У сучасних складних економіко-політичних умовах для ефективного функціонування підприємства важсливи $\epsilon$ визначення стратегї управління підприємством заради попередження економічних втрат. Особливо гостро постає питання максимізації прибутку при мінімальних інвестиціях у виробництво. Особливо проблемною галуззю промислового комплексу Украӥни є легка промисловість, оскільки в останні роки ї̈ частка у загальній промисловості Украйни скоротилася $i$ нині, за статистичними даними, становить менше 1\%. [17] У иій статті розглядається питання моніторингу виробничої діяльності швейного підприємства за допомогою математичного моделювання. Досліджуване підприємство займається виробництвом за двома технологіями. Було визначено основні параметри виробничих функцій, щоб по кожній з двох інвестувати в основні види ресурсів (праця та капітал) задля максимізації накопиченого прибутку підприємства, а також запропоновано методи чисельного розв'язання иієё задачі. Модель може бути застосована до будь-якого швейного підприємства, щчо виробляє продукиію за неоднорідними технологіями.

Ключові слова: підприємство легкої промисловості, оптимальне керування, принцип максимуму Понтрягіна, праця, капітал.

В современных сложных экономико-политических условиях для эффрективного функиионирования предприятия важным является определение стратегии управления предприятием ради предупреждения экономических потерь. Особенно остро стоит вопрос максимизации прибыли при минимальных инвестициях в производство. Особенно проблемной отраслью промышленного комплекса Украинь является легкая промышленность, поскольку в последние годы ее доля в общей промышленности Украины сократилась и сейчас, по статистическим данным, составляет менее 1\%. [9] В этой статье рассматривается вопрос мониторинга производственной деятельности швейного предприятия с помощью математического моделирования. Исследуемое предприятие занимается производством по двум технологиям. Были определены основные параметры производственных функиий, чтобы по каждой из двух инвестировать в основные виды 
ресурсов (труд и капитал) для максимизачии накопленной прибыли предприятия, а также предложены методы численного решения этой задачи. Модель может быть применена к любому швейного предприятия, производящего продукиию по неоднородным технологиям.

Ключевые слова: предприятие легкой промышленности, оптимальное управление, принцип максимума Понтрягина, труд, капитал.

In today's difficult economic and political conditions, for the efficient business operation it is important to determine the company management strategy to prevent economic losses. Particularly acute is the issue of profits maximization with minimal investments in production. Highly problematic sector of industrial complex of Ukraine is the light industry. In recent years its share in the total industry of the country has decreased to $1 \%$, according to the latest statistics [17]. This article reviews the issue of constructing a mathematical manufacturing model in the company of light industry, which uses two different technologies in production. Author determines the main parameters of production functions for each of the two technologies and finds the optimal control which resolves how and when the profits should be distributed to reinvest in the main types of resources (material and labour) to maximize gained company profit, suggesting the methods of numerical solution of this problem. The model can be applied to any company which manufactures products with heterogeneous technologies, including companies of light industry.

Keywords: light industry enterprise, optimal control, Pontryagin maximum principle, labour, capital.

Вступ. Легка промисловість є однією 3 ключових галузей економіки, оскільки вона відіграє важливу роль у забезпеченні потреб внутрішнього ринку держави та сприяє іï економічній незалежності від імпортних товарів. Потенціальні можливості підприємств легкої промисловості дозволяють виробляти широкий спектр товарів, здатних задовольнити увесь попит внутрішнього ринку. Практично всі підприємства легкої промисловості приватизовані. Діяльність кожного підприємства $є$ важливою не тільки для його власників у контексті прибутку, а й для держави у контексті забезпечення їі добробуту в цілому.

Моделювання діяльності підприємства (зокрема, підприємства легкої промисловості) розглядається такими вченими, як А. П. Гречан [4], С.С. Аптекар [1], Ю. В. Шерстенніков [15], Л. М. Наумова [9], Г. В. Свсєєва [5], О. М. Васьків [3], Н. С. Бєляєва [2], М. М. Повідайчик [13], Д. І. Шиндирук [16].

Важливим процесом для підприємства $\epsilon$ визначення оптимальної стратегії, яка пов'язана з розподілом прибутку на реінвестування в капітал та споживання, з метою максимізації прибутку на наступному етапі. Ефективним методом вирішення цієї задачі може бути застосування апарату оптимального керування.

Модель включає в себе показники, за допомогою яких можна визначити, як необхідно розподілити наявні ресурси (працю та капітал) для того, щоб отримати максимальний накопичений прибуток, що i $\epsilon$ кінцевою метою діяльності будь-якого підприємства. У даній моделі цими показниками є: темп приросту робочої сили; частка робочої сили, що припадає на першу 
технологію виробництва; коефіцієнт капіталізації (норма реінвестування); частка прибутку, що спрямована на зростання капіталу, що зайнятий у першій технології виробництва. Розв'язання моделі має вказувати на оптимальні значення цих показників для підприємства, а також показувати, яку саме стратегію та поведінку підприємству необхідно здійснити.

Постановка завдання. Необхідно побудувати економіко-математичну модель виробничої діяльності підприємства легкої промисловості, що використовує 2 види технологій виробництва. Визначити основні параметри виробничих функцій та знайти керуючі параметри, що визначають, як і коли саме необхідно розподіляти отриманий прибуток на реінвестування в основні види ресурсів (праця та капітал) задля максимізації накопиченого прибутку підприємства.

Методологія. Для розв'язання поставленої задачі було використано модель 3 неоднорідними технологіями [12] та модель розвитку малого підприємства 3 мультиплікативною виробничою функцією Кобба-Дугласа [15].

Для запропонованої моделі було використано інструментарій теорії оптимального керування (принцип максимуму Понтрягіна), метод найменших квадратів (МНК), а також чисельні методи розв'язання крайових задач та задач Коші, зокрема метод стрільби та метод Ейлера.

Результати дослідження. Було розглянуто економіко-математичну модель малого підприємства 3 двофакторною мультиплікативною виробничою функцією, що дозволяє розраховувати динаміку його розвитку в залежності від затрат на розвиток основних виробничих фондів та оплату праці. Поставлено задачу виконати чисельний аналіз залежності динаміки розвитку малого підприємства від основних параметрів виробництва.

Побудуємо спрощену модель динаміки розвитку швейного підприємства, яка базується на припущеннях:

- у виробництві задіяно 2 різні технології, які задаються у моделі різними виробничими функціями: а) виробництво шовкових тканин, прядіння штучних та синтетичних волокон; б) оздоблення тканин та текстильних виробів;

- технології виробництва у період моделювання є незмінними;

- на виробничу діяльність підприємства впливають такі фактори: праця i капітал;

- уся вироблена продукція миттєво реалізується на ринку;

- у разі відсутності виробництва фірма припиняє свою діяльність.

Кожна виробнича технологія підприємства може бути описана двофакторною неокласичною мультиплікативною виробничою функцією Кобба-Дугласа, що залежить від фонду оплати праці та капіталу: 


$$
\begin{aligned}
& F_{1}\left(K_{1}(t), L_{1}(t)\right)=X_{1}(t)=A_{1} K_{1}^{\alpha_{1}}(t) L_{1}^{\beta_{1}}(t), \\
& F_{2}\left(K_{2}(t), L_{2}(t)\right)=X_{2}(t)=A_{2} K_{2}^{\alpha_{2}}(t) L_{2}^{\beta_{2}}(t) .
\end{aligned}
$$

Де $X_{1}(t), X_{2}(t)$ - обсяги випусків продукції за кожною технологією у грошовому вимірі;

$K_{1}(t), K_{2}(t)$ - обсяги виробничих фондів за кожною технологією у грошовому вимірі;

$L_{1}(t), L_{2}(t)$ - обсяги трудових ресурсів, що витрачаються на кожну технологію, у грошовому вимірі;

$A_{1}, A_{2}, \alpha_{1}, \alpha_{2}, \beta_{1}, \beta_{2}-$ коефіцієнти виробничих функцій.

У більшості випадків випуск продукції обмежений виробничою потужністю обладнання. Тому при збільшенні чисельності працівників до нескінченності виробництво пропорційно зростати не може. Отже, необхідно модифікувати формули (1) - (2), щоб при $L_{1}(t), L_{2}(t) \rightarrow \infty$ виконувалися умови: $X_{1}(t) \rightarrow A_{1} K_{1}^{\alpha_{1}}(t), X_{2}(t) \rightarrow A_{2} K_{2}^{\alpha_{2}}(t)$. Для цього замінимо $L_{1}^{\beta_{1}}(t)$ і $L_{2}^{\beta_{2}}(t)$ у формулах (1) - (2) на $\left(1-e^{\left(-\frac{\beta_{1} \cdot L_{1}(t)}{K_{1}(t)}\right)}\right) \mathrm{i}\left(1-e^{\left(-\frac{\beta_{2} \cdot L_{2}(t)}{K_{2}\left(t_{2}\right)}\right)}\right)$ відповідно та отримаємо:

$$
\begin{aligned}
& F_{1}\left(K_{1}(t), L_{1}(t)\right)=X_{1}(t)=A_{1} K_{1}^{\alpha_{1}}(t)\left(1-e^{\left(-\frac{\beta_{1}-L_{1}(t)}{K_{1}(t)}\right)}\right), \\
& F_{2}\left(K_{2}(t), L_{2}(t)\right)=X_{2}(t)=A_{2} K_{2}^{\alpha_{2}}(t)\left(1-e^{\left(-\frac{\beta_{2}-L_{2}(t)}{K_{2}(t)}\right)}\right)
\end{aligned}
$$

Звідси маємо загальний обсяг випуску:

$$
X(t)=X_{1}(t)+X_{2}(t)
$$

Також загальний обсяг трудових ресурсів $L(t)$ дорівнює сумі обсягів трудових ресурсів, що зайняті у кожній технології та перерозподіляється між ними у кожний наступний момент часу $t$ за допомогою коефіцієнта $q(t)$ (частка робочої сили, що припадає на першу технологію виробництва) [12]:

$$
\begin{gathered}
L(t)=L_{1}(t)+L_{2}(t), \\
L_{1}(t)=q(t) L(t), 0 \leq q(t) \leq 1, \\
L_{2}(t)=(1-q(t)) L(t) .
\end{gathered}
$$

Зміну обсягу робочої сили (вираженого у грошових коштах) можна подати у вигляді: 


$$
\frac{d L}{d t}=v(t) L(t)
$$

де $v(t)$ змінюється в часі та означає темп приросту робочої сили $(a \leq v(t) \leq b)$.

Позначимо $c s_{1}\left(c s_{2}\right)$ - питома собівартість випуску продукції за першою (другою) технологією у вартісному вираженні. Ця змінна визначає, яку суму необхідно витратити, щоб випустити одиницю продукції, якби іiі вартість становила 1 грн..

Тепер можна визначити, яку величину загального прибутку матимемо від виробництва:

$$
P_{s a z}(t)=\left(1-c s_{1}\right) X_{1}(t)+\left(1-c s_{2}\right) X_{2}(t),
$$

Введемо такі змінні:

$\mu_{1}\left(\mu_{2}\right)$ - амортизація капіталу за першою (другою) технологією;

$c(t), 0 \leq c(t) \leq 1$ - коефіцієнт капіталізації, що змінюється в часі $\mathrm{i}$ показує, яка частка загального прибутку спрямована на поновлення капіталу (постійних та змінних матеріальних ресурсів) за обома технологіями;

$m(t), 0 \leq m(t) \leq 1-$ коефіцієнт, що змінюється в часі та означає частку прибутку, що спрямована на збільшення капіталу, що зайнятий у першій технології.

Динаміку зміни обсягу капітальних вкладень, виражених у грошових коштах, у кожну з технологій можна визначити за такими правилами [11]:

$$
\begin{gathered}
\frac{d K_{1}}{d t}=c(t) m(t) P_{\text {saz }}(t)-\mu_{1} K_{1}(t), \\
\frac{d K_{2}}{d t}=c(t)(1-m(t)) P_{\text {saz }}(t)-\mu_{2} K_{2}(t) .
\end{gathered}
$$

Якщо $\tau$ - це ставка податку на прибуток, то величина податку у кожний момент часу буде дорівнювати [15]

$$
N(t)=\tau(1-c(t)) P_{s a z}(t) .
$$

А величина чистого прибутку:

$$
P(t)=(1-\tau)(1-c(t)) P_{\text {saz }}(t) .
$$

Тоді для того, щоб знайти прибуток за весь період $T$, необхідно знайти значення такого інтеграла: 


$$
P_{f i n}(T)=\int_{0}^{T} P(t) d t \rightarrow \max
$$

Об’єднавши формули (3) - (12) та (14) - (15), отримаємо модель виробничої діяльності підприємства легкої промисловості.

Для знаходження максимального значення накопиченого за період $T$ прибутку необхідно розв'язати задачу оптимального керування [7] 3 такими параметрами керування: $q(t), v(t), c(t), m(t)$.

Метою роз'язання задачі оптимального керування буде мінімізація критерію якості [6]:

$$
I=-\int_{0}^{T}(1-c(t))(1-\tau) P_{\text {saz }}(t) d t \rightarrow \min .
$$

Параметрами системи виступають $L(t), K_{1}(t), K_{2}(t)$. Також відомі значення у початковій точці, тобто у нульовий момент часу:

$$
L(0)=L_{0}, K_{1}(0)=K_{10}, K_{2}(0)=K_{20} \text {. }
$$

Задачу такого типу не можна розв'язати без застосування принципу максимуму Понтрягіна [14], тому необхідно сформулювати гамільтоніан:

$$
\begin{gathered}
H=\sum_{i=0}^{n} \psi_{i}(t) f_{i}, \psi_{o}(t)=-1 ; \\
H=(1-c(t))(1-\tau) P_{\text {saz }}(t)+ \\
+\psi_{1}(t) v(t) L(t)+\psi_{2}(t)\left[c(t) m(t) P_{\text {saz }}(t)-\mu_{1} K_{1}(t)\right]+ \\
+\psi_{3}(t)\left[c(t)(1-m(t)) P_{\text {saz }}(t)-\mu_{2} K_{2}(t)\right] \rightarrow \max .
\end{gathered}
$$

Тут $\psi_{1}(t), \psi_{2}(t), \psi_{3}(t)$ - спряжені до заданих (9), (11) - (12) функції, що визначаються такими співвідношеннями:

$$
\begin{array}{r}
\dot{\psi}_{1}(t)=-\frac{d H}{d L}, \\
\dot{\psi}_{2}(t)=-\frac{d H}{d K_{1}{ }^{\prime}} \\
\dot{\psi}_{3}(t)=-\frac{d H}{d K_{2}} .
\end{array}
$$


Що стосується знаходження оптимальних функцій керування, то вони є точками екстремуму гамільтоніана [6]. Для їх знаходження продиференціюємо гамільтоніан по кожній функції керування. Для $q(t)$ це матиме вигляд:

$$
\begin{gathered}
\frac{d H}{d q}=\frac{d P_{3 a z}}{d q}\left((1-c(t))(1-\tau)+\psi_{2}(t) c(t) m(t)+\right. \\
\left.+\psi_{3}(t) c(t)(1-m(t))\right) .
\end{gathered}
$$

У формулі (23) $\frac{d P_{3 a z}}{d q}$ визначається таким виразом:

$$
\begin{aligned}
& \frac{d P_{s a z}}{d u_{1}}=\left(1-c s_{1}\right) A_{1} K_{1}^{\alpha_{1}-1}(t) \beta_{1} L(t) e^{\left(\frac{\beta_{1} q(t) L(t)}{K_{1}(t)}\right)}- \\
& -\left(1-c s_{2}\right) A_{2} K_{2}^{\alpha_{2}-1}(t) \beta_{2} L(t) e^{\left(\frac{\beta_{2}(1-q(t)) L(t)}{K_{2}(t)}\right)} .
\end{aligned}
$$

3 отриманого виразу робимо висновок, що керування $q(t)$ буде оптимальним у разі, якщо

$$
\frac{d P_{\text {saz }}}{d q}=0
$$

Розв'язавши (25), отримаємо значення оптимального керування $q(t)$ у кожний момент часу моделювання:

$$
q(t)=\frac{\beta_{2} L(t) K_{1}(t)+K_{1}(t) K_{2}(t) \ln \frac{\left(1-c s_{1}\right) A_{1} K_{1}^{\alpha_{1}-1}(t) \beta_{1}}{\left(1-c s_{2}\right) A_{2} K_{2}^{\alpha_{2}-1}(t) \beta_{2}}}{L(t)\left(\beta_{2} K_{1}(t)+\beta_{1} K_{2}(t)\right)} .
$$

Тепер продиференціюємо гамільтоніан по кожній функції керування $v(t), c(t), m(t)$ :

$$
\begin{gathered}
\frac{d H}{d v}=\psi_{1}(t) L(t), \\
\frac{d H}{d c}=P_{s a z}(t)\left[-(1-\tau)+\psi_{2}(t) m(t)+\psi_{3}(t)(1-m(t))\right], \\
\frac{d H}{d m}=P_{s a z}(t) c(t)\left[\psi_{2}(t)-\psi_{3}(t)\right] .
\end{gathered}
$$

3 (27) - (29) бачимо, що гамільтоніан $є$ лінійним по всіх трьох управліннях $v(t), c(t), m(t)$. На практиці це означає, що кожне з зазначених керувань буде оптимальним у кожний момент часу у крайній точці інтервалу, 
яким він обмежений [10]. Тобто керування буде оптимальним у своїй лівій границі, коли $\frac{d H}{d x}<0, x=\{v, c, m\}$, та у своїй правій границі, коли $\frac{d H}{d x} \geq 0, x=\{v, c, m\}$. Маємо:

$$
\begin{aligned}
& v(t)=\left\{\begin{array}{l}
\text { a, якио } \psi_{1}(t) L(t)<0, \\
\text { b, якио } \psi_{1}(t) L(t) \geq 0 ;
\end{array}\right. \\
& c(t)=\left\{\begin{array}{l}
0, \text { якио } P_{\text {sаa }}(t)\left[\tau-1+\psi_{2}(t) m(t)+\psi_{3}(t)(1-m(t))\right]<0, \\
1, \text { лкияо } P_{\text {sаz }}(t)\left[\tau-1+\psi_{2}(t) m(t)+\psi_{3}(t)(1-m(t))\right] \geq 0 ;
\end{array}\right. \\
& m(t)=\left\{\begin{array}{l}
0, \text { якио } P_{\text {заз }}(t) c(t)\left[\psi_{2}(t)-\psi_{3}(t)\right]<0, \\
1, \text { якио } P_{\text {заг }}(t) c(t)\left[\psi_{2}(t)-\psi_{3}(t)\right] \geq 0 .
\end{array}\right.
\end{aligned}
$$

Запишемо умови трансверсальності. Оскільки критерій якості (16) містить тільки інтегральну складову [8], вони будуть виглядати так:

$$
\psi_{1}(T)=0, \psi_{2}(T)=0, \psi_{3}(T)=0 .
$$

Зауважимо, що протягом усього періоду моделювання фонди $L(t)$ та два види капіталу $K_{1}(t)$ та $K_{2}(t)$ - додатні, оскільки в іншому випадку підприємство закривається та моделювання припиняється:

$$
L(t), K_{1}(t), K_{2}(t)>0 .
$$

Для прикладу розглянемо підприємство легкої промисловості, що має назву Приватне акціонерне товариство "Волинський шовковий комбінат" i займається діяльністю за двома технологіями.

На основі статистичних даних за 2003-2006 pp. із застосуванням методу найменших квадратів було визначено коефіцієнти виробничих функцій. Також визначаємо відповідно відносні показники амортизації та питомої собівартості:

- технологія виробництва тканин, прядіння штучних та синтетичних волокон: $A_{1}=0,25, \alpha_{1}=1,11, \beta_{1}=-90,16, \mu_{1}=0,18, c s_{1}=0,65$;

- технологія обробки та оздоблення тканин та текстильних виробів: $A_{2}=0,1, \alpha_{2}=1,37, \beta_{2}=-10,01, \mu_{2}=0,26, c s_{2}=0,53$;

Побудована модель вимагає початкових умов. Приймемо за точку відліку 2003 рік. Тоді

$$
\begin{aligned}
& K_{1}(0)=36,583 \text { млн. грн., } \\
& L_{1}(0)=1,458 \text { млн. грн., } \\
& K_{2}(0)=33 \text { млн. грн., } \\
& L_{2}(0)=0,506 \text { млн. грн. }
\end{aligned}
$$


Об'єднавши все вищезазначене, маємо систему з 6 диференціальних рівнянь (9), (11) - (12), (20) - (22) з 3 початковими (17) та 3 кінцевими (33) умовами, тобто крайову задачу, що може бути розв'язана із застосуванням чисельних методів, а саме методу стрільби розв'язання крайових задач та методу Ейлера для розв'язання задачі Коші кожної з ітерацій методу стрільби.

Реалізувавши обрахунки за допомогою середовища $\mathrm{C}++$ iз застосуванням перелічених методів та взявши за розрахунковий період 10 років, отримаємо такі результати:

- більшу частину досліджуваного часу (приблизно 6,5 років) весь отриманий прибуток вкладається у виробництво, тому дорівнює нулю. Але наступний етап - це накопичення прибутку: оскільки виробничі потужності були покращені протягом моделювання, прибуток накопичується інтенсивніше (рис. 1):

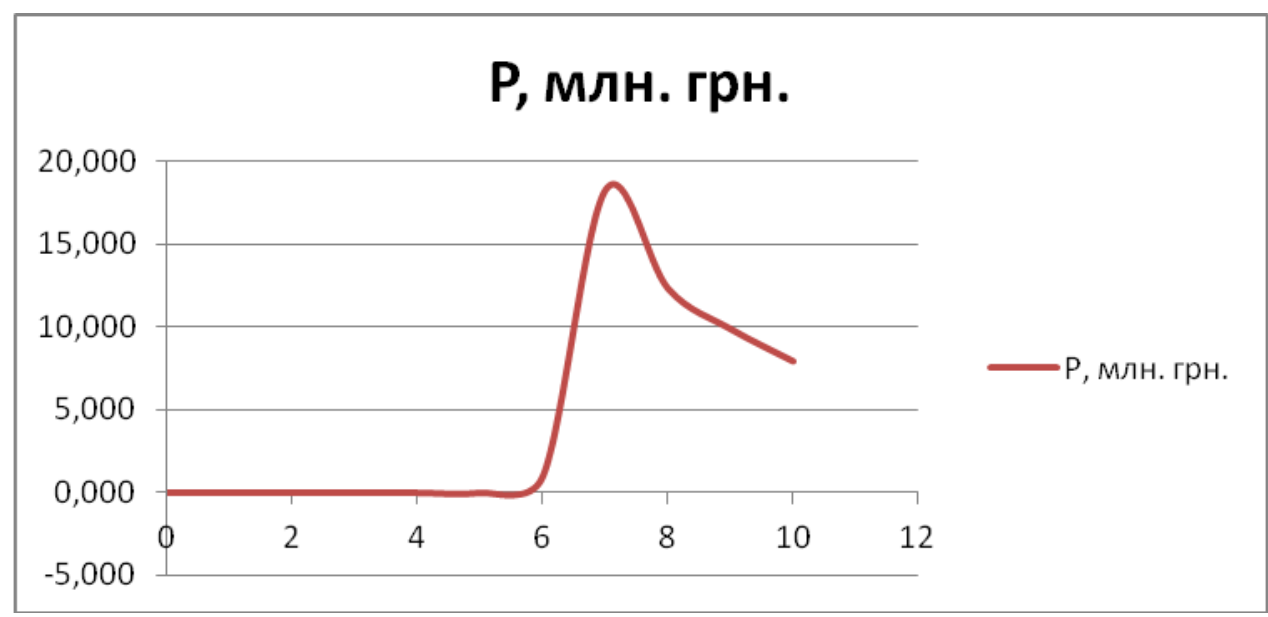

Рис. 1. Значення прибутку підприємства, розраховані за допомогою запропонованої моделі

- приблизно 4,5 роки прибуток спрямовується виключно на розширення виробництва за першою технологією (ткацтво, прядіння), потім ще близько 2 років - виключно на розширення другого виробництва (обробка, оздоблення тканин) (рис.2):

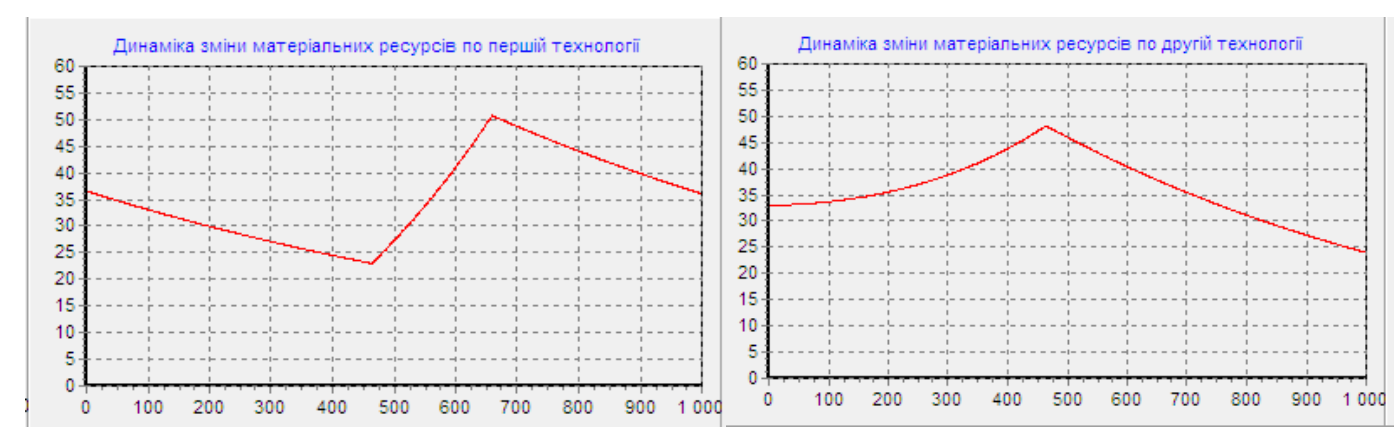

Рис 2. Динаміка зміни капіталу по першій та другій технології 
- що стосується зміни обсягу робочої сили, зайнятої на підприємстві, то іï динаміку можна поділити на 2 періоди: активний набір працюючих (6,5 років) та зменшення їх кількості (3,5 роки) (рис. 3$)$ :

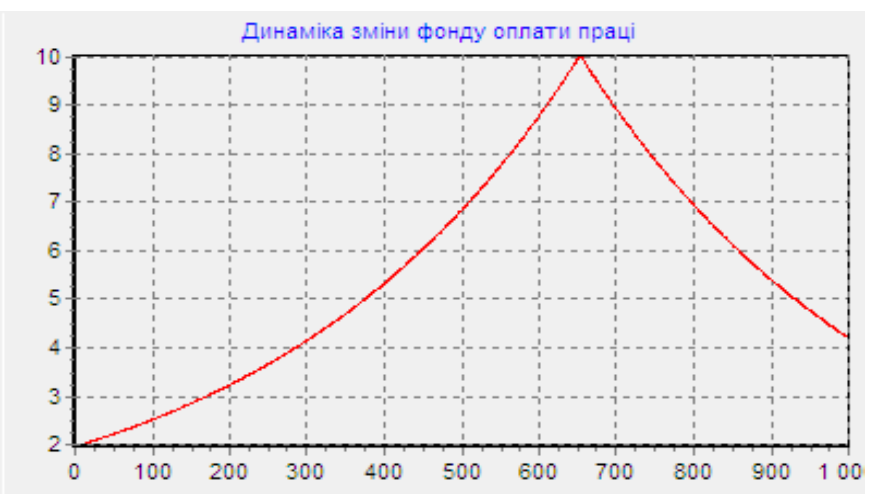

Рис 3. Динаміка зміни праці у грошовому вираженні

- $\quad$ за весь період прибуток досягає значення 48,401 млн. грн.

Також, порівнявши прибутки, розраховані за допомогою моделі, та прибутки, які фактично були отримані підприємством за цей період (рис.4), можемо помітити, що фактично підприємство було прибутковим протягом усього періоду часу (36,984 млн. грн. за 10 років), проте оптимальний сумарний прибуток отримаємо за допомогою застосування оптимальної стратегії, що була знайдена у моделі.

Відмінність отриманих даних від статистичних зумовлена переважно такими факторами:

- прагнення підприємця якнайшвидше максимізувати свій прибуток і його небажання йти на ризик;

- недоотримання прибутку через неповну реалізацію продукції.

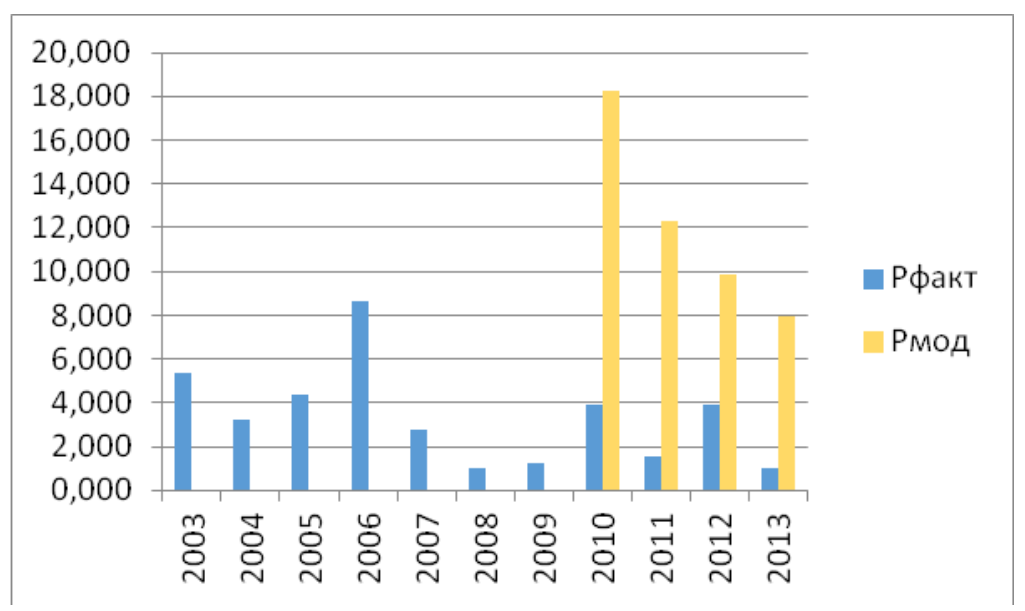

Рис. 4. Значення прибутків підприємства 
Порівнявши фактичні дані 3 даними, що отримані за допомогою програмної реалізації моделі, отримаємо, що оптимальна стратегія дає можливість отримати сумарний прибуток, що на 30,9\% перевищує фактично отриманий. Тобто, розподіл матеріальних та трудових ресурсів по технологіях та своєчасне інвестування прибутку у виробництво дає можливість отримувати вищі прибутки.

Висновки. У даній роботі була сформульовано економіко-математичну модель виробничої діяльності підприємства легкої промисловості, що використовує 2 види технологій виробництва. Визначено основні параметри виробничих функцій та знайдено керуючі параметри, що визначають, як і коли саме необхідно розподіляти отриманий прибуток на реінвестування в основні види ресурсів (праця та капітал) задля максимізації накопиченого прибутку підприємства

Параметрами системи виступають: матеріальні ресурси по кожній 3 технологій, фонд оплати праці. Критерієм якості $\epsilon$ накопичений чистий прибуток підприємства. Параметрами управління системи є: темп приросту робочої сили; коефіцієнт капіталізації; коефіцієнт, що показує, яка частка загального реінвестованого прибутку буде спрямована на збільшення матеріальних ресурсів першої технології; частка робочої сили, що спрямована на першу технологію виробництва.

Було визначено, що у разі застосування оптимальної стратегії накопичений сумарний прибуток підприємства збільшується, у розглянутому прикладі це було збільшення на 30,9\%.

Враховуючи недостатність статистичних даних і інформації в даній області в Україні, важко змоделювати виробничу діяльність підприємства. Тож для максимальної відповідності побудованої системи реальному стану деякого економічного об'єкта необхідне вдосконалення і більш детальне дослідження предметної області.

\section{Література:}

1. Аптекар С. С. Інвестиційне середовище легкої промисловості / С. С. Аптекар, Ю. В. Нефьодова. - Донецьк : Донбас, 2014. - 191 с.

2. Бєляєва Н. С. Сумісна оптимізація виробничої програми та витрат на виробництво продукції підприємствами швейної промисловості / Н. С. Бєляєва. // Проблеми і перспективи розвитку підприємництва. - 2014. - №2 (1). - С. 56-59.

3. Васьків О. М. Економіко-математичне моделювання витрат ресурсів на виготовлення продукції підприємство легкої промисловості / О. М. Васьків. // Науковий вісник НЛТУ України. - 2009. - Вип. 19.2. - С. 290-296.

4. Гречан А. П. Інноваційний розвиток легкої промисловості України / А. П. Гречан. Київ, 2004. - 267 с.

5. Євсєєва Г. В. Формування логістичної системи на підприємствах легкої промисловості : автореф. дис. на здобуття наук. ступеня канд. ек. наук : спец. 08.00 .04 
"Економіка та управління підприємствами (легка промисловість)" / Євсєєва Галина Володимирівна - Київ, 2007. - 24 с.

6. Интрилигатор М. Математические методы оптимизации и экономическая теория / М. Интрилигатор. - : Айрис-пресс, 2002. - 576 с.

7. Кузнецов Ю. А. Применение систем компьютерной математики в задачах оптимального управления экономическими системами / Ю. А. Кузнецов, А. В. Семенов. Нижний Новгород : 2007. - 98 с.

8. Лагоша Б. А. Оптимальное управление в экономике: теория и приложения: учеб. пособие / Б. А. Лагоша, Т. Г. Апалькова. - М. : Финансы и статистика, 2008. - 224 с.

9. Наумова Л. М. Стратегія і механізми розвитку підприємств легкої промисловості: науково-практичний аспект / Наумова Л. М. - Херсон : Грінь Д. С., 2013. - 422 с.

10. Охорзин В. А. Оптимизация экономических систем. Примеры и алгоритмы в среде Mathcad / В. А. Охорзин. - М. : Финансы и статистика, 2005. - 144 с.

11. Охріменко М. Г. Методи дослідження операцій / М. Г. Охріменко, І. Ю. Дзюбан. Київ : Політехніка, 2005. - 108 с.

12. Перестюк М.О. Сучасний економічний аналіз. Макроекономіка / М.О. Перестюк, О.І. Пономаренко, В.М. Бурим - Київ: Вища школа, 2004. - 207 с.

13. Повідайчик М. М. Особливості стратегічного планування виробничої програми підприємства легкої промисловості в умовах невизначеності / М. М. Повідайчик. // Науковий вісник Ужгородського університету. - 2014. - №1 (42). - С. 59-63.

14. Понтрягин Л.С. Математическая теория оптимальных процессов / Л.С. Понтрягин М., В.Г. Болтянський, Р.В. Гамкрелидзе, Е.Ф. Мищенко, М: Наука, 1976. - 391 с.

15. Шерстенников Ю. В. Динамическая модель развития малого предприятия с мультипликативной производственной функцией Кобба-Дугласа / Ю. В. Шерстенников. // Актуальні проблеми екноміки. - 2008. - №1 (79). - С. 228-234.

16. Шиндирук I. П. Економіко-математичне моделювання та оптимізація структури капіталу підприємств / І. П. Шиндирук. // Фінанси України. - 2012. - №2. - С. 111-120.

17. Державна служба статистики України [Електронний ресурс]. - Режим доступу : http://www.ukrstat.gov.ua/, вільний. - Загол. з екрану. 